$\begin{array}{ll}\text { UNIVERSITY OF LONDON } \\ 19 & \begin{array}{l}\text { INSTITUTE OF LATIN AMERICAN STUDIES } \\ \text { RESEARCH PAPERS }\end{array}\end{array}$

The Mexican Landlord:
Rental Housing in
Guadalajara and Puebla

Alan Gilbert and Ann Varley 


\section{The Mexican Landlord: Rental Housing in Guadalajara and Puebla}

\section{Alan Gilbert and Ann Varley}

Institute of Latin American Studies

31 Tavistock Square, London WC1H 9HA 
ISBN 0901145661

ISSN 0957-7947

(C)Institute of Latin American Studies,

University of London, 1989 


\section{CONTENTS}

Introduction 1

Methodology 3

Landlords in Guadalajara and Puebla 5

Size of operation 5

Landlord residence and forms of rental housing 5

Wealth 9

$\begin{array}{ll}\text { The origins of renting } & 10\end{array}$

The Economics of Landlordism 12

Rent levels 12

The economic returns 17

$\begin{array}{ll}\text { Conclusion } & 23\end{array}$

$\begin{array}{ll}\text { Appendix } & 24\end{array}$

$\begin{array}{ll}\text { Notes } & 28\end{array}$

$\begin{array}{ll}\text { Bibliography } & 31\end{array}$ 
Alan Gilbert is Reader in Geography at University College London and the Institute of Latin American Studies

Ann Varley is Lecturer in Geography at University College London 


\section{The Mexican Landlord: Rental Housing in Guadalajara and Puebla}

\section{Introduction}

For many years rental housing has been in relative decline in Mexico. More and more families have become owner-occupiers, mainly in the vast self-help settlements that surround most Mexican cities. The proportion of owneroccupiers in urban Mexico rose from 33.7 per cent in 1950 to 57.1 per cent in $1980 .{ }^{1}$ Despite this fact, renting continues to be important: indeed, the absolute numbers of tenant households increased two and a half times between 1950 and $1980 . .^{2}$ In addition, it is possible that the 1980 s have seen a reversal of the recent shift towards home ownership. As a result of the recession, income levels have fallen, making home ownership difficult for both the poor and the middle classes (Gilbert and Varley, 1988). The Mexican government has realised that renting can no longer be ignored and under President de la Madrid (1982-88) it began to encourage private builders to construct for rent. Other incentives are likely in the future if the costs of housing construction continue to rise in real terms, making both formal and informal sector construction too expensive for the majority of Mexican families.

In order to stimulate rental housing it is, of course, necessary to know who lets accommodation. Unfortunately, there is very little data available on landlords in Mexico. Neither the academic literature nor government publications provide us with adequate information; in fact, we know far more about landlords in nineteenth-century Britain than we do about their equivalents in today's Mexico. Such a gap in our knowledge is not peculiar to Mexico: there are few cities in Latin America for which adequate data are available.

The limited literature provides us with a highly superficial picture of the Latin American landlord. We are not even sure of the scale of most forms of landlordism although we suspect that large landlords are no longer a major influence in the housing market. In Colombia, for example, landlords are mainly owner-occupiers and even absentee landlords rarely own more than two or three properties. Not infrequently the principal form of accommodation is provided in consolidating self-help set $t$ lements where resident owners rent out individual rooms. Petty landlordism seems to be the rule and is part 
of the process by which the more established owners try to increase their incomes. In Bogotá, "most landlords are themselves poor and are renting one or two rooms in their own house to supplement their own limited incomes. Renting seems an essential part of the home consolidation process; without tenants, ownership would be more difficult for the landlords" (Gilbert, 1983, p.472). A similar pattern is evident in Santa Cruz, Bolivia, and in Mexico City (Green, 1988; Gilbert and Ward, 1985). In the latter, Coulomb (1985, p.52) reports that "the landlords of the urban periphery are .... labourers, employees, traders, bricklayers or artisans" and only onethird of the landlords had constructed the dwelling specifically to rent it.

In Latin America, the nature of landlordism has clearly changed during the years; the large-scale landlord used to be much more prominent. In nineteenth- and early twentieth-century Argentina, landlords frequently owned numerous conventillos producing a good income; they were "among the richest and most respected men of Buenos Aires" (La Prensa, cited in Scobie, 1974, p.154). Similarly, in Rosario, renting property was "a popular form of business among the most influential .... of 'decent' society" (Armus and Hardoy, 1984, p.40). In Chile, the respectability of the landlord was no doubt enhanced by the fact that in Santiago, the priesthood was a substantial property owner (Violich, 1944, p.73). It was also helped in places by the fact that the middle classes continued to live in rented accommodation. In Mexico, rental housing remained the principal form of middle-class housing until the early 1950s; an older propertied class remained intact despite the Revolution and was joined by a number of revolutionary leaders who had invested in urban property in the 1920s and 1930s (Perló, 1981, pp.13 and 44).

Gradually, however, the profitability of this type of investment was falling and capital began to seek out alternative areas of investment. The rent controls introduced during the Second World War were a further discouragement. While we have too little information to be absolutely certain, it seems that few among the elite now invest in rental housing in Latin American cities. There has been little interest in investing in new rental property for many years.

For these reasons, we are interested in the nature of the Mexican landlord. In particular, we are concerned with the kinds of landlord who rent homes to the urban poor - the group who make up the bulk of Mexican tenants. By the urban poor we are broadly referring to the poorest half of the income distribution. In this paper, we describe the nature of landlords and landlordism in Guadalajara and Puebla, where we carried out a housing study in 1985 (Gilbert and Varley, 1988). 


\section{Methodology}

This paper describes the nature of landlords and the economics of landlordism, both in the central city tenement areas and in the consolidated 'selfhelp' settlements. Based on interviews with landlords, a large household survey and a detailed listing of residential tenure in four settlements, the paper examines the main characteristics of landlords, how and when they began to let accommodation, and the rationale that underlies their investment in rental housing. In the Appendix we provide a number of case studies of individual landlords to illustrate the points made in the paper.

Guadalajara and Puebla were selected as case studies because they both have a high level of tenancy and non-ownership by Mexican standards. Both are large cities, with around three million and one million inhabitants respectively, and both are continuing to grow rapidly. Most of the primary data were collected during field work between August 1985 and September 1986. A random survey of 411 tenant households was carried out, 216 in Guadalajara and 195 in Puebla. In addition, interviews with 47 landlords were also conducted. ${ }^{3}$ In each city, two kinds of settlement were studied: one located in the central area and containing numerous large tenement properties; the other situated in the well-consolidated self-help neighbourhoods.

The first kind of settlement chosen was intended to represent the central rental areas to be found in most large Latin American cities. Many tenants were expected to live in single rooms, sharing communal services, in large, deteriorated vecindades. ${ }^{4}$ The houses in these areas are typical of the housing once occupied by the people Turner (1967) described as 'bridgeheaders' - newly-arrived migrants to the cities. While the urban reception areas are now spread much more widely throughout the city (Edwards, 1982; Gilbert and Ward, 1982; Brown 1972; Conway and Brown, 1980), central vecindades remain important sources of rental accommodation. The two settlements chosen, Central Camionera in Guadalajara and Analco in Puebla, were both located within two kilometres of the central cathedral.

The second kind of neighbourhood chosen was intended to represent a well-consolidated and serviced self-help settlement. Renting was expected to be well established within the settlement, with approximately equal numbers of owners and tenants. In Guadalajara, Agustín Yáñez was selected in the east of the city. Seven kilometres from the cathedral, it had been founded by illegal subdivision in the early 1950 s. $^{5}$ In Puebla, we chose Veinte de Noviembre, a settlement located about four kilometres to the north-west of the cathedral and founded by illegal subdivision in the 1940 s.

Interviews were conducted with either the man or the woman householder and data were collected on the whole household since its formation. Information was obtained about place of birth, migration history and employment; about the household's size, structure, income, residential history and 
quality of accommodation; and about attitudes to past and future residential choice. ${ }^{6}$ The tenants were asked about their landlords, previous rental accommodation, the conditions of their tenancy, and their interest in becoming owner-occupiers. ${ }^{7}$

In addition, a separate survey was conducted among landlords. Unfortunately, this survey could not be based on a rigorous sample because it proved impossible to identify every landlord. Resident landlords were no problem but non-resident owners were often elusive. Tenants were the main source of information about the landlords but in Analco and particularly in Central Camionera many did not know the address, or sometimes even the name of their landlord. Landlords were not interviewed unless they were known to have more than one tenant: we did not wish to cause tenants any embarrassment. This procedure limited our choice of landlords, particularly in Agustín Yáñez and Central Camionera. Eventually, ten landlords were interviewed in Guadalajara and thirty-seven in Puebla. Qualitative rather than quantitative information was sought in the interviews with the landlords, some of whom talked with us for an hour or more. They were asked about how they became landlords, about the nature of their property, how they determined appropriate rent levels, how they chose tenants, how and why they evicted households, how they managed their properties, and about the general economic, political and legal environment which faced them. Interviews were also conducted with a dozen representatives of firms managing rental property. Most of these were located in Puebla where a higher proportion of landlords appeared to use such firms. 


\section{Landlords in Guadalajara and Puebla}

\section{Size of operation}

Our evidence strongly suggests that most landlords in the two cities operate on a small scale. Thirty of the landlords interviewed lived in the property where they let rooms; a further seven owned only one rental property; halfa-dozen landlords owned two or three rental properties. Of course, larger operators exist: in Guadalajara, one landlord in Agustín Yáñez owned a vecindad for fifteen tenant households and at least five other properties; another, in Central Camionera, owned eight flats and a house for rent. ${ }^{8}$

Further evidence from Puebla supports the idea that there are relatively few large-scale landlords in the city. Cadastral data on the central Analco area showed that few owners had more than one property. In addition, representatives of several rental companies agreed that most letting was on a small scale: the largest landlord on any of their books was probably receiving no more than one million pesos per month (at the time, the equivalent of about $£ 1,000$, or twenty times the minimum salary). This scale of holding was very unusual, and the most lucrative rental holdings were mostly in middleclass areas of the city. However, one caveat is necessary: the administrators admitted that the largest landlords in Puebla tend to manage their own property. ${ }^{9}$ In Guadalajara, the overall picture of small-scale landlordism is generally similar. The municipal official in charge of the vecindad inspection programme reported that it was unusual for a landlord to own more than one property. Again, however, there must be a minor reservation: if small-scale ownership is indeed the norm, the situation would appear to have changed markedly since 1960 . A survey conducted in that year recorded that 361 owners between them controlled 1,762 vecindades; forty per cent of these properties were in the hands of 42 owners, giving an average of 17 properties apiece (Ramírez Jiménez, 1978). ${ }^{10}$

The apparent lack of large-scale landlords is linked to the absence of institutional landlords. In fact, we discovered only one example of the latter. This was a charitable medical foundation, created in the 1960s by a family with a considerable amount of rental housing in the centre of Puebla. The income from their vecindades was used to support a clinic run by the foundation. In the opinion of the current director, however, the rental properties are today more of a liability than an asset to the foundation. If this view is correct, it is not surprising that we found little evidence of businesses engaged in residential letting.

\section{Landlord residence and forms of rental housing}

Some landlords live with their tenants; others live in the same settlement; a few do not even live in Mexico. In Guadalajara, few landlords lived with their tenants but in Puebla almost one-quarter of all tenants had a resident landlord (Tables 1, 2, and 3). ${ }^{11}$ The resident landlord was found more 
frequently in the older-established self-help settlements of both cities than in the central areas. Too much should not be made of this distinction, however, for there were many more tenants with resident landlords in the centre of Puebla than in the older self-help settlement in Guadalajara. Among nonresident landlords, only a minority seemed to live in the same settlement; the majority of tenants said their landlord lived somewhere else in the city. Some landlords even lived outside the city, particularly in Guadalajara, where a number of landlords lived elsewhere in Jalisco and several were in the United States. Such absentee landlordism was almost unknown in Puebla.

Table 1: Landlord's Place of Residence

\begin{tabular}{|c|c|c|c|c|c|c|}
\hline \multirow[b]{2}{*}{$\begin{array}{l}\text { Percentage of } \\
\text { tenants who } \\
\text { reported landlord } \\
\text { resident in: }\end{array}$} & \multicolumn{3}{|c|}{ Guadalajara } & \multicolumn{3}{|c|}{ Puebla } \\
\hline & OSS* & CCS & All & OSS & CCS & All \\
\hline $\begin{array}{l}\text { Same plot } \\
\text { Same area } \\
\text { Same city } \\
\text { Outside the city } \\
\text { U.S.A. }\end{array}$ & $\begin{array}{r}14 \\
16 \\
58 \\
4 \\
8\end{array}$ & $\begin{array}{r}0 \\
17 \\
60 \\
22 \\
1\end{array}$ & $\begin{array}{r}7 \\
16 \\
59 \\
14 \\
5\end{array}$ & $\begin{array}{r}27 \\
29 \\
40 \\
4 \\
0\end{array}$ & $\begin{array}{r}19 \\
16 \\
63 \\
1 \\
2\end{array}$ & $\begin{array}{r}22 \\
21 \\
53 \\
2\end{array}$ \\
\hline Total & 100 & 100 & 100 & 100 & 100 & 100 \\
\hline Sample size & 71 & 77 & 148 & 73 & 97 & 170 \\
\hline $\begin{array}{l}\text { Percentage of } \\
\text { tenants reporting } \\
\text { that they did not } \\
\text { know where land- } \\
\text { lord lived: }\end{array}$ & 26 & 36 & 32 & 9 & 16 & 13 \\
\hline
\end{tabular}

Landlords own a wide variety of types of property. Such variation is apparent both within the individual settlements and across the two cities; there are also significant differences between the two cities (Tables 2 and 3). Multi-occupancy buildings were the dominant form of rental property in Puebla. Only four per cent of tenants lived on their own, in properties accounting for 22 per cent of those visited. In contrast, in Guadalajara, twofifths of all tenants lived on their own and three-quarters of all the property listed in our household counts was of this kind. Not surprisingly, large rental properties were more common in Puebla than in Guadalajara (Tables 3 and 4). In both cities, approximately one tenant in four lived in accommodation with ten or more other households (Table 3 ). There were more large proper- 
ties in the central areas, although some were also found in the self-help areas. The largest properties that we found had 59 tenants in Guadalajara and 64 in Puebla.

A further variation concerns the use of some rental properties to house members of the landlords' own family ${ }^{12}$ In Puebla, various properties housed sharers as well as owners and tenants; this gives rise to a greater diversity of property types and tenure mixes than in Guadalajara.

\section{Table 2: Different Types of Rented Property in the Survey Settlements}

\begin{tabular}{|c|c|c|c|c|c|c|}
\hline \multirow[b]{2}{*}{$\begin{array}{l}\text { Percentage of } \\
\text { rented plots with: }\end{array}$} & \multicolumn{3}{|c|}{ Guadalajara } & \multicolumn{3}{|c|}{ Puebla } \\
\hline & OSS & CCS & All & OSS & CCS & All \\
\hline $\begin{array}{l}\text { Resident landlord } \\
+ \text { tenant }(s)^{*} \\
\text { One tenant }\end{array}$ & 6 & 0 & 3 & 26 & 21 & 23 \\
\hline household only & 77 & 75 & 76 & 33 & 13 & 22 \\
\hline $\begin{array}{l}\text { Several tenants } \\
\text { without landlords* }\end{array}$ & 17 & 25 & 22 & 41 & 66 & 55 \\
\hline Total & 100 & 100 & 100 & 100 & 100 & 100 \\
\hline Sample size & 142 & 194 & 336 & 173 & 205 & 378 \\
\hline $\begin{array}{l}\text { Rented plots as a } \\
\text { percentage of all } \\
\text { residential plots }\end{array}$ & 42 & 58 & 50 & 35 & 64 & 46 \\
\hline
\end{tabular}

Notes:

A complete residential plot survey was carried out in the two rental settlements in Puebla. In Guadalajara, the plot/household listing was based on a sample of 9 blocks (50 per cent of the total) in the older self-help settlement (Agustín Yáñez) and of 11 blocks (13 per cent of the total) in the central city settlement (Central Camionera). The small minority of plots for which insufficient information was obtained are excluded from the calculations.

* Some plots also include households who are neither owners nor tenants - for example, sharers, or 'caretakers' in vecindades. 
Table 3: Tenant Households Occupying

Different Types of Rented Property in the

Survey Settlements

Percentage of tenant households

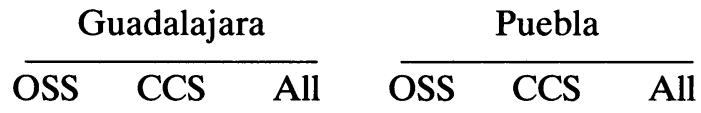
occupying rented plots with:

Resident landlord:

—household listing

-qn. survey

15

0

$6 \quad 34$

20

24

10

$5 \quad 25$

One tenant only:

-household listing

29

33

10

$39 \quad 16$

$\begin{array}{ll}2 & 4 \\ 1 & 7\end{array}$

Several tenants without landlord:

-household listing

-qn. survey

42

Total:

-household listing

-qn. survey

Sample size:

-household listing

-qn. survey

Percentage of tenants living in properties with:

1 household

2-5 households

6-10 households

$11+$ households

No. of households

unknown

All

Sample size

$\begin{array}{rrrrrr}100 & 100 & 100 & 100 & 100 & 100 \\ 100 & 100 & 100 & 100 & 100 & 100 \\ & & & & & \\ 280 & 493 & 773 & 566 & 1,368 & 1,934 \\ 96 & 120 & 216 & 80 & 115 & 195\end{array}$

Notes:

The percentage of tenants living on plots with a resident owner differs from that in Table 1 because of the different sample size. In some cases, it was known that the landlords did not live on the same plot, but their exact address was not known; these cases could be included in this table, but had to be counted as missing cases in Table 1.

Not all households living on a plot are bound to be tenants, except when there is only one household in all. 'No. of households unknown' almost always refers to cases where there are at least two households on the plot. 
Table 4: Size of Rental Properties in the Two Cities

\begin{tabular}{|c|c|c|c|c|c|c|}
\hline \multirow[b]{2}{*}{$\begin{array}{l}\text { Mean number of } \\
\text { households living } \\
\text { on plots with: }\end{array}$} & \multicolumn{3}{|c|}{ Guadalajara } & \multicolumn{3}{|c|}{ Puebla } \\
\hline & OsS & $\mathrm{CCS}$ & All & OSS & CCS & All \\
\hline $\begin{array}{l}\text { Resident landlord } \\
+ \text { tenant(s)* }\end{array}$ & & & & & & \\
\hline -All & 4.8 & - & 4.8 & 4.2 & 6.2 & 5.2 \\
\hline -Tenants only & 3.8 & - & 3.8 & 2.8 & 5.0 & 3.9 \\
\hline $\begin{array}{l}\text { One tenant } \\
\text { household only: }\end{array}$ & & & & & & \\
\hline -Tenants only & 1.0 & 1.0 & 1.0 & 1.0 & 1.0 & 1.0 \\
\hline $\begin{array}{l}\text { Several tenants } \\
\text { without landlord*: }\end{array}$ & & & & & & \\
\hline -All & 5.3 & 7.1 & 6.5 & 4.5 & 7.9 & 6.7 \\
\hline -Tenants only & 5.3 & 7.1 & 6.5 & 4.5 & 7.8 & 6.6 \\
\hline $\begin{array}{l}\text { All rented plots: } \\
\text {-All }\end{array}$ & 20 & 2.5 & 23 & 3.3 & 67 & 51 \\
\hline -Tenants only & 1.9 & 2.5 & 2.3 & 2.9 & 6.3 & 4.8 \\
\hline No. of plots & 142 & 194 & 336 & 173 & 205 & 378 \\
\hline
\end{tabular}

Source: Household listing - see Table 2.

* The number of households includes the owner and/or households with other types of tenure, where present.

\section{Wealth}

Some landlords are wealthy and some are rather poor; in our interviews we encountered a wide range of income groups. The causes of variation, however, are rather unpredictable and there seems to be no clear relationship between the wealth of the landlord and a series of variables such as location of the property, the manner in which people became landlords, or their place of residence.

However, the better-off landlords seem to have one thing in common: they tend to run their own business in addition to their rental interests. Indeed, it is this business that is usually the main source of their income. The family of one wealthy landlord in central Puebla owned a couple of businesses selling dress materials and a general store. They had built a block of sixteen flats at the front of their large property in Analco, and received approximately half their income from renting these flats. Another landlord in this area had a business exporting onyx craftware, which accounted for two-thirds of his income, the rest coming from ten flats which he had built himself. Most of these wealthier landlords owned property in the central area. 
The majority of landlords, however, were not wealthy and some were decidedly poor. Perhaps the most extreme case was an elderly landlady who rented her own accommodation in a vecindad near Analco. ${ }^{13}$ The most obvious link between these poorer landlords was that many were elderly, mainly older couples or widows. Many of the men were retired but others were still active, often in some kind of self-employment. The range of activities was wide, although commercial activities and skilled manual trades were frequently mentioned. There were also some younger widowed or abandoned women in this group of poorer landlords.

The percentage contribution of rent to these landlords' monthly incomes was highly variable. The more affluent landlords rarely reported that rent was the most important component, although the amount received from rent was nonetheless significant. Two landlords with sixteen and thirty tenants respectively received the equivalent of seven times the minimum salary, although the average for those with between ten and thirty tenants was around four times the minimum salary. A few of the more affluent landlords claimed to receive less than ten per cent of their income from rent, but the figure was more often between half and one-quarter. As might be expected, more of the poorer landlords were completely dependent on the rent. However, the total income derived from rent was seldom substantial and it did not generally constitute a high proportion of landlords' monthly income. In Guadalajara, landlords with between two and six tenants received on average the equivalent of about one-and-a-half times the minimum salary from rent; in Puebla, the average for poorer landlords, with similar numbers of tenants, was less than one minimum salary. ${ }^{14}$

\section{The origins of renting}

There are various routes into the business of renting: some landlords bought property, some inherited it, and others built it themselves. While these routes into landlordism would seem to be very different, they often overlapped; indeed, a few landlords had acquired property through a variety of methods.

A few landlords had bought property with the express intent of letting it. Among these were a number who were getting on in years and who wanted a secure income to support them and their families in their old age. One couple had bought a vecindad property in Agustín Yánez when the man was 63 years old. He had made some money from agriculture and intended the income from the property to support his wife and himself through their old age. Lacking children or other relatives this was needed as the equivalent of a pension. In hindsight, he thought that he had made a mistake; he could have gained a more secure income through putting his money in the bank.

The second and seemingly most common route into landlordism is through inheritance: most of the landlords with whom we talked had had the property, and the associated problems, wished upon them. Indeed, in central Puebla a number of properties had been passed down through several 
generations. One elderly landlady had inherited a vecindad from her grandfather who had built the property after he had migrated from rural Oaxaca in the mid-nineteenth century. Another landlord, who operated the worst vecindad we encountered, had also inherited it from his father; the father had in turn inherited it from his parents.

Renting in Mexico is often described as a 'widow's business'. The term derives from the time when property was a good investment and when a widow could live well from inherited property. Today, however, the term is also used in a more derogatory sense: it is only widows that remain in the business. Whatever the precise sense, a few landlords did buy property with the intention of leaving it to their wives when they died. ${ }^{15}$ Others bought it for their children, as something to pass on. One man of 69, for example, had bought a fifteen-family vecindad in the centre of Puebla for his daughter. ${ }^{16}$.

Finally, there are the landlords who have built property themselves. A landlady in Puebla now had thirty tenants in three different properties in the city. Over the years she had bought land and gradually constructed flats to let. Other landlords had inherited land or property and later extended the business. A middle-class landlord in the centre of Guadalajara had partially converted the house he inherited from his mother and rented out four flats. He had also built flats elsewhere in the city. We found few other landlords, however, who had invested in new purpose-built accommodation.

The only substantial constructors were what we have called the 'self-help landlords'. These 'self-help landlords' normally began by building their own home and then gradually extended the property. Such extensions often took a long time and we interviewed several landlords who had purchased property in the 1950s, but not begun to let until the 1970s or 1980s. Clearly, for most of them, extending the property for rental purposes was a method of supplementing the family income. However, the strategy of building accommodation for rent in order to finance improvements to the family home was not common: we encountered only two landlords who had begun to rent within a couple of years of purchasing their plots. Indeed, we suspect that many of these self-help landlords drifted into landlordism. Certainly, several of them had only begun to let rooms once their children had grown up and left home. A few are undoubtedly drifting out again: we found several cases where the tenants had been evicted in order to make room for grown-up children and their families. We also found several plots with a combination of landlords, sharers and tenants.

Among these self-help landlords were several who had inherited plots from their parents. This was especially common in the central area of Puebla, where one part of Analco was not developed until the 1940s, but it was not uncommon even in the consolidated self-help settlement. ${ }^{17}$ This underlines the point that the different routes into renting frequently coalesce. Self-help landlords sometimes inherit property; middle-class owners extend property that they have inherited; some landlords purchase a plot and build upon it. Whatever their route into landlordism, however, few believe it to be a profitable investment. 


\section{The Economics of Landlordism}

\section{Rent levels}

In Mexico, conflicting claims are constantly being made about rent levels; tenants claim rents are too high; landlords, that they are too low. Without getting too far into the question of what constitutes the basis for a fair and equitable rent, it is necessary to establish certain facts about rent levels in the two cities in 1985 and 1986.

First, to judge by international standards rent levels in Guadalajara and Puebla were not high relative to household incomes. The survey data show that the mean proportion of income going in rent was 13 per cent. Even for those earning less than one minimum salary, the mean rent/income share was only 16 per cent. By comparison, World Bank estimates for thirteen cities in less-developed countries demonstrate that rent/income shares vary from a high of 22 per cent in Seoul to a low of 7 per cent in Cairo. Table 5 and Figure 1 show that if the rent/income shares of those earning less than US\$50 is considered, the range is from 77 per cent in Seoul to 10 per cent in Cairo (Malpezzi and Mayo 1987b). Unlike income/expenditure patterns, average rent/income shares rise as cities become more prosperous: "as income increases from Cairo, to Manila, to Bogotá, and then to Seoul-so, too, does the average fraction of income allocated to housing" (Mayo, 1985, p.5). If this interpretation of the data is correct, the housing/income shares of Guadalajara and Puebla should fall between those of Bogotá and Seoul. In fact, the mean rent/income ratios were considerably lower than those of Bogotá.

Table 5: Rent/Income Shares by City and Income Group: Percentage of households/income per month (US dollar-equivalent)

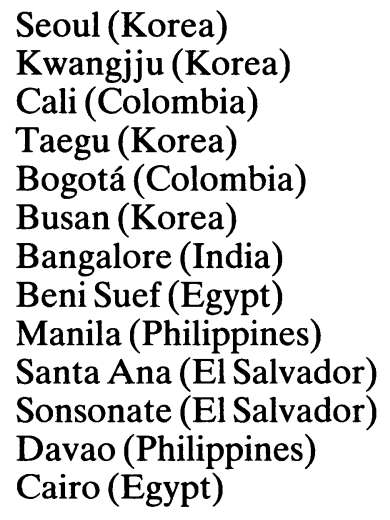

$$
\$ 50 \quad \$ 100 \quad \$ 150 \quad \$ 300 \text { City average }
$$

$\begin{array}{rrrrr}77 & 52 & 42 & 29 & 22 \\ 46 & 35 & 30 & 23 & 21 \\ 47 & 32 & 25 & 17 & 19 \\ 53 & 36 & 28 & 19 & 18 \\ 33 & 26 & 23 & 18 & 18 \\ 68 & 42 & 32 & 20 & 16 \\ 12 & 9 & 8 & 6 & 10 \\ 11 & 8 & 6 & 5 & 9 \\ 23 & 17 & 14 & 10 & 9 \\ 17 & 12 & 9 & 7 & 8 \\ 15 & 11 & 9 & 6 & 8 \\ 9 & 9 & 8 & 8 & 8 \\ 10 & 7 & 6 & 4 & 7\end{array}$

Source: Malpezzi and Mayo (1987b, p.210). 
Figure 1: Rent/Income Shares by Household Income in LDC Cities

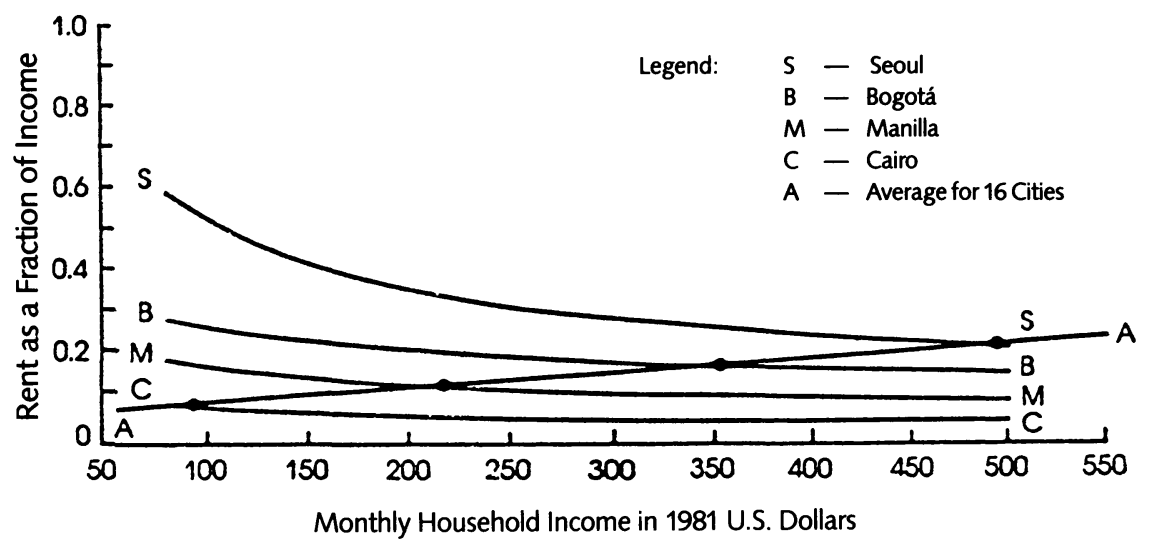

Table 6: Rent/Income Shares by Income Group in

Guadalajara, Puebla and Bogotá (percentage)

\begin{tabular}{|c|c|c|c|c|c|}
\hline \multirow[b]{2}{*}{ Income } & \multicolumn{2}{|c|}{ Guadalajara } & \multicolumn{2}{|c|}{ Puebla } & \multirow{2}{*}{$\frac{\text { Bogotá }}{\mathrm{SS}^{\mathrm{a}}}$} \\
\hline & OSS & CCS & OSS & $\mathrm{CCS}$ & \\
\hline Groups & & & & & \\
\hline 1 & 26 & 22 & 27 & 10 & 42 \\
\hline 2 & 13 & 19 & 12 & 12 & 20 \\
\hline 3 & 9 & 10 & 9 & 9 & 14 \\
\hline 4 & 7 & 6 & 8 & 4 & 9 \\
\hline 5 & 8 & 5 & - & - & 10 \\
\hline 6 & 7 & - & 3 & $n g^{b}$ & $\mathrm{ng}^{\mathrm{b}}$ \\
\hline 7 & - & 7 & - & - & $n g^{b}$ \\
\hline Sample size & 70 & 69 & 52 & 67 & 105 \\
\hline
\end{tabular}

Notes:

Household income ranges are: $1=0-1.0$ minimum salary, $2=1.01-2.0$ minimum salaries etc.

${ }^{\text {a }}$ Four self-help settlements (SS) which cannot be disaggregated as a result of small sample size.

b Negligible

To take comparison further, rent/income data from Guadalajara and Puebla have been compared in Table 6 to those found in similar kinds of 
settlements in Bogotá (Gilbert, 1983). In the latter, rent/income shares seem to be somewhat higher. If we look at the figures by income group, the shares are much higher for the lowest three income groups in Bogotá. This is especially interesting insofar as the Guadalajara and Puebla figures were collected during a recession when the rent/income shares might be expected to have risen; the comparison suggests that rents in the two cities were relatively low.

It is also interesting to compare the latter figures with the rent/income shares in Mexico City in 1970. After a decade when rents had risen fifty per cent faster than prices in general, almost half of middle-income families were paying between 0 and 10 per cent of their income in rent and a further 39 per cent between 11 and 20 per cent (Slovik, 1972).

Second, the general proposition that rent levels were not high in Guadalajara and Puebla in 1985 and 1986 is also supported by the relationship between changes in rents and prices since 1970. During the 1970s, in fact, rent levels rose more slowly than prices in general. Table 5 shows that the costs of housing (rents, fuel and light) rise broadly in line with prices, except in years of rapid inflation. Whenever the general rate of inflation has risen rapidly, the housing/general-index ratio appears to have fallen. This is most obvious in the periods $1973-4,1976-7$, and $1982-7$. The most dramatic change in the ratio occurred during the rapid inflation of the 1980s; in 1981, the two indices were more or less equal; by July 1987 the general index was almost twice that of the housing index.

It would be misleading, however, to compare housing costs only with the general price index. Housing costs should also be compared to levels of income, for despite the overall trend it is possible that rents have risen more rapidly than incomes. Table 7 also attempts to compare trends in rents with the minimum salary. The data show that although there was a general decline in the housing/minimum salary ratio during the 1970s, during most of the 1980 s the ratio was fairly steady.

It is only after the Pacto de concertación was introduced in 1988 that rent levels began to rise substantially faster than the minimum salary. As a result of the government's anti-inflation policy, the minimum salary was permitted to rise by only 11 per cent during 1988 . In contrast, and despite the aim of the government, rents rose by 84 per cent. Despite the limits to rent rises laid down in the legislation operating in several Mexican cities, landlords continued to raise rents by roughly the same amount as they had during the previous six years of rapid inflation.

A glance at Table 7 suggests that the rise in 1988 may be exceptional. Past experience has been that landlords have failed to raise rents in line with changing prices when the general inflation rate has suddenly accelerated. Equally, they have failed to limit rent rises when the rate of price rises generally has fallen. In fact, there seem to be signs of a lagged response by land- 
lords to the general rate of inflation. If this is correct, rent rises during 1989 should be much more limited.

\section{Table 7: Inflation, Housing Costs and}

Minimum Salaries 1970 - 87

\begin{tabular}{|c|c|c|c|c|}
\hline & \multicolumn{2}{|r|}{$\begin{array}{l}\text { Rate of inflation } \\
\quad \text { (per cent) }\end{array}$} & $\begin{array}{l}\text { Housing cost/ } \\
\text { general price } \\
\text { index (July) }\end{array}$ & $\begin{array}{l}\text { Housing cost/ } \\
\text { minimum salary } \\
\text { (July) }\end{array}$ \\
\hline 1970 & & 3.8 & 1.16 & 1.39 \\
\hline 1971 & & 4.2 & 1.16 & 1.46 \\
\hline 1972 & & 5.0 & 1.17 & 1.30 \\
\hline 1973 & & 12.0 & 1.13 & 1.41 \\
\hline 1974 & & 23.8 & 1.02 & 1.16 \\
\hline 1975 & & 15.2 & 1.01 & 1.08 \\
\hline 1976 & & 15.8 & 1.03 & 1.04 \\
\hline 1977 & & 20.7 & 0.97 & 0.93 \\
\hline 1978 & & 16.2 & 1.00 & 1.00 \\
\hline 1979 & & 20.0 & 0.99 & 1.01 \\
\hline 1980 & & 29.8 & 0.96 & 1.05 \\
\hline 1981 & & 28.7 & 0.97 & 1.05 \\
\hline 1982 & & 98.9 & 0.93 & 1.19 \\
\hline 1983 & & 80.8 & 0.82 & 1.13 \\
\hline 1984 & & 59.2 & 0.75 & 1.10 \\
\hline 1985 & & 63.7 & 0.70 & 1.04 \\
\hline 1986 & & 105.7 & 0.68 & 1.13 \\
\hline 1987 & & 159.2 & 0.58 & 1.03 \\
\hline 1988 & & 51.7 & 0.60 & 1.22 \\
\hline 1989 (Janu & ary) & & 0.71 & 1.50 \\
\hline \multicolumn{5}{|c|}{$\begin{array}{ll}\text { Notes: } & \\
\text { Inflation } & - \text { annual figures for } 1 \text { Jaunuary }-31 \text { December. } \\
\text { Indices } & -1978=100 . \\
\text { Minimum } & - \text { average minimum salary for country on } 1 \text { July each year. } \\
\text { salary } & \text { Clearly, rises in the minimum salary are somewhat jerky } \\
& \text { so that there are sudden variations in the ratio when the } \\
& \text { minimum salary changes. }\end{array}$} \\
\hline
\end{tabular}

Sources: Banco de México Indice Nacional de Precios al Consumidor: cuadro III - I; Comisión Nacional de los Salarios Mínimos, Salarios Mínimos.

There are several ways of explaining the trend up to 1988. First, if the Mexican rental legislation is effective - and we are by no means sure how effective it is - then rents are bound to fall relative to incomes during a period of rapid inflation. During an existing contract landlords are not permitted to raise the rent by more than a set proportion of the rise in the minimum salary. Since the minimum salary has been increasing more slowly than prices, this would be sufficient to explain the fall in rents relative to prices in general. It would not, of course, explain why rents rose marginally faster than the minimum salary during most of the 1980s and certainly not the major jump in 1988 . 
A second explanation of the slow rises before 1988 is that many landlords put up the rent of current tenants with some reluctance. While many raise the rents when the annual contract is renewed, others fail to do so. Many landlords do not like discussing rents with tenants especially when they have known them for some time; some shy away from dealings with recalcitrant tenants. The only time when landlords are free of such constraints is when a tenancy is terminated. This distinction would be of little significance were it not for the fact that the average current tenancy in our survey settlements is lengthy - it varies from a minimum of three years in the older self-help settlements to eight or nine years in the central areas (median value; Gilbert and Varley, 1988). If landlords fail to raise the rents of existing tenants in line with prices generally and those tenants stay in the property for several years, the real value of rents will fall. During a period of rapid inflation, it does not take long for rents to drop behind the general price level and behind the general income level. Such an argument is supported by cross-national findings: Malpezzi and Mayo (1987a, p.705) report that "length of tenure and housing expenditures are negatively related in all estimates". It is also compatible with practice in Los Angeles where rent rises for new tenants are far higher than those of existing tenants (Malpezzi and Rydell, 1986, p.11).

Third, even when the contract is terminated and a free market rate can be negotiated, it is less than certain that landlords obtain rises equivalent to those of prices in general. As one rental administrator in Puebla argued, rents cannot be raised continuously because people simply do not have the money. This would certainly explain the implicit link shown in Table 7 between rises in rents and the minimum salary. It is also compatible with the impressions gained from interviews that, while some landlords extract all they can from new tenants, many landlords are much less economically rational. One Puebla landlord claims to set the rent according to the tenants' means; another puts it up a little to cover small repairs to the flats; others 'occasionally' put up rents when tenants change. Again, however, this explanation does not account for the changes after 1987.

Finally, lowish rents are compatible with the trend towards owneroccupation in most Mexican cities since 1940. Elsewhere we have shown that the cost of unserviced peripheral land relative to incomes is quite low in Guadalajara and Puebla. Earlier information for Mexico City also suggests that ejido land was relatively cheap compared to plots in pirate subdivisions in Bogotá (Gilbert and Ward, 1985). If this is the case, then it is logical to believe that rents will also be low. If rents were raised in line with inflation, larger numbers of tenants would opt to become owner-occupiers on the periphery. Of course, such a change cannot be made instantly, but there ought to be a general relationship between the cost of peripheral land and the level of rents.

Of course, all this information is circumstantial. It also conflicts with some of our other findings, notably that there is no shortage of tenants in Guadalajara and Puebla. Our argument also diverges from the claims of several studies that rents in Mexico City are increasing more rapidly than inflation 
(Portillo, 1984; Méndez Rodríguez, 1987). Nonetheless, we believe that the evidence, such as it is, supports the idea that rents up to 1988 were low both relative to prices and relative to incomes. This is not, of course, the same as saying that poor households find it easy to pay the rent. Under a generally inflationary situation and with falling real incomes, they are faced with major budgetary problems. It is, however, compatible with what the majority of landlords were saying during 1985-6: that renting was not a good business.

\section{The economic returns}

Few of the landlords interviewed in Guadalajara and Puebla are likely to become wealthy on the strength of their rental income. The maximum received by any of the landlords was seven times the minimum salary. ${ }^{18}$ The majority of landlords interviewed received the equivalent of less than one minimum salary from rent.

Out of these rents, landlords have certain expenses to cover, principally the cost of water and property taxes. In fact, such outgoings are generally modest and most landlords had considerable difficulty in remembering how much they had to pay. Only a couple of landlords mentioned them as major problems. Landlords living on their property would in any case have to pay the same amount in property taxes whether or not they had tenants. Some landlords should also be liable to income tax on their rental income, although few, if any, of the landlords actually pay it. ${ }^{19}$ The only major expense, therefore, is the cost of maintenance; although many landlords get round this problem by failing to repair their properties.

With receipts often amounting to little more than a minimum salary from renting, it is very difficult to see how building a new rental property in lowincome areas of the city can be a sound business proposition. It is almost equally difficult to see how buying an existing property can give a reasonable rate of return on investment. The opinions expressed by landlords amply confirmed this view. The great majority were absolutely clear: renting is bad business. Typical comments were "no, you couldn't really call it a business", "no, it's not a business", "no, no, no! Right now, renting houses is the worst, really the worst, business you could name", and "no, it's the worst business I've ever got involved in". One landlord, who was very unusual in having bought his rented property within the last year, admitted that "I've put my foot in it". Renting was considered a poor business mainly because rents are low, but landlords also complained that maintenance costs were so high that they couldn't afford to repair their property. The lack of repairs means that the property deteriorates over time, ensuring that rents remain low. Renting is not only bad economics: it is also an unpleasant and inconvenient business. Collecting the rent is a headache both because it is a physical chore and because of the difficulty of extracting the money from tenants who do not pay on time. Putting up with aggressive tenants, and getting rid of bad tenants, are difficulties which landlords could do without. As one landlord said: "I'd get three times as much if I had the money in the bank, and the cheque would be delivered to me here, no problems". 
Within this general chorus of disgruntlement, there are a few dissenting voices. One landlady admitted that low rents made letting a poor business, but noted that it was a secure source of income, and "any help is a good thing". This sense of the income from rent 'helping' in some, albeit minor, way was conveyed by all eight of the landlords who dissented from the generally very poor opinion of renting. The main advantage was the guarantee of receiving some money in the form of rent. Tenants would always require accommodation, and so renting "is a business which doesn't end". It was especially valued by old people without any other regular source of income. Help from relatives cannot be counted on by all old people, and even some of the reluctant landlords acknowledged that renting had certain attractions in this respect. The prospect of rents providing an income, however low, for one's old age is one reason why many landlords continue to rent out property. The traditional saying that "I'm going to retire, and live off my rents", is still partially true.

Other landlords explicitly acknowledged their lack of business logic in continuing to rent. Some admitted that they kept their property mostly for sentimental reasons. One landlord in the centre of Guadalajara keeps his inherited property "in memory of my parents". ${ }^{20}$ Another landlord kept his colonial vecindad in Analco mostly as an inheritance from his parents, and as somewhere to live for himself and his family. He actively disliked having strangers on the plot and intended to reduce the number of rented rooms if and when economic circumstances allowed. Others kept the property so that they would have something to leave to their children.

Landlords were also commonly following a now outmoded business rationale - the 'traditional' belief, among those with money to invest in Mexico, that it should be put into real estate rather than into banks. ${ }^{21}$ The persistence of such belief in the face of evidence to the contrary is more readily understandable when it is remembered that most landlords are drawn from an older generation. The few landlords interviewed who had invested in property in recent years were old men. They were also from relatively poor backgrounds, working, for example, in agriculture. They were clearly not shrewd businessmen.

Approximately one-quarter of the landlords interviewed intended either to reduce the number of rooms they were renting or to sell the property; a number of them were in fact already trying to do so. In practice, the difficulties they were encountering in selling suggest that one reason why landlords continue to rent is that they are trapped in it. One man had tried unsuccessfully to sell his vecindad in Agustín Yáñez; a woman who had inherited property in the same settlement was also trying to sell. One landlord owning property in Central Camionera had already sold one of his four flats to an employee; he wanted to sell all the property and thought it good for his employees to have the responsibility of home ownership. ${ }^{22}$ Landlords probably have a better chance of selling to tenants than to other landlords. Several families in a vecindad in Analco had successfully come to an agreement 
with their landlord to buy their homes; at least one other landlord in the same area was reported to be selling off flats to the tenants. However, there is a major problem: few tenants have the money to buy outright and bank loans are both very expensive and very difficult to obtain. ${ }^{23}$ Landlords are also unwilling to let tenants pay in instalments, because of the high level of inflation. As a result, although both sides may be willing to transfer ownership, the situation often becomes a stalemate.

Some landlords are less interested in selling the property to their tenants than in refurbishing it and selling it off as a condominium. To do this, however, they first have to evict the existing tenants. This sometimes proves difficult. In central Puebla, a young landlord was planning either to sell his property of six flats or pull it down. Three of the six tenants had already left, but he was involved in a conflict with the others, who neither wanted to leave nor to buy their flat from him. He was worried that they would take him to court, which would mean he had to wait even longer before he could get them out and convert his property for sale.

In seeking to convert their rented housing into condominia, landlords were following a general trend of rental disinvestment. Rental administrators and representatives of landlord organisations interviewed in the two cities admitted that selling property was more profitable than renting it. Although the organisations concerned administered property in mostly middle-class areas, they reportedly found renting just as bad a business as the landlords of property in the case-study areas. The return from renting, which traditionally had yielded around 1 per cent of the property's value per month, was now producing only 0.2 per cent. Owners generally were "pushing to sell", mostly by converting and selling off rented flats for owneroccupation or for offices. Although some rental property was still coming onto the market, and although the agencies were still getting some new owners as clients, the administrators were agreed that the current climate was one of stong disinvestment. ${ }^{24}$

The conversion of property into condominia is profitable providing that the property is sufficiently attractive to attract purchasers, that credit is available for buyers without ready cash, and that the owner can mobilise the capital to cover the costs of conversion and improvements. Currently, however, credit is very expensive and often unavailable. This has left the owners of ageing rental property, particularly vecindades in the city centre, with no real option but to try to sell the property as it stands. A number of vecindades in each city carried signs advertising their sale, and occasionally properties were advertised in the local newspapers. In general, however, rental property was not moving. A survey of ownership changes in Analco revealed a generally low level of turnover of properties; its results are summarised in Table 8. Almost three-fifths of the plots in Analco have not changed hands since 1970 and approximately one-fifth of them have not changed hands at all since $1950 .{ }^{25}$ The conclusion is that ownership patterns are very stable. 
Table 8: Changes of Plot Ownership in Analco, $1950-86$

\begin{tabular}{crrrr} 
& \multicolumn{5}{c}{$\begin{array}{c}\text { Percentage of plots changing } \\
\text { ownership since year started }\end{array}$} \\
$\begin{array}{c}\text { Number of changes of } \\
\text { ownership known to } \\
\text { have occurred }\end{array}$ & 1950 & 1960 & 1970 & 1980 \\
0 & 21 & 34 & 57 & 87 \\
1 & 42 & 42 & 34 & 12 \\
2 & 24 & 16 & 7 & 2 \\
3 & 10 & 4 & 2 & 0 \\
4 & 2 & 1 & ng & 0 \\
5 or more & 1 & 2 & 0 & 0 \\
Total & 100 & 100 & 100 & 100 \\
Number of plots & 220 & 305 & 302 & 312
\end{tabular}

Note:

Care should be exercised when comparing data across the years because the number of missing cases varies, particularly for the 1950 s: thus, a property whose earliest recorded change of ownership is, for example, 1956, is lost from the 1950 column, and if the owner in 1978 is not the same as the owner recorded in 1964, without adequate information being available to date the change between these years, the plot will be included in the base for the 1960 and 1980 columns, but not the 1970 one.

Source: Data from the Dirección de Catastro, Secretaría de Finanzas del Estado de Puebla.

If rented property cannot be sold, then the only other alternative is to sell it for its site value. This is an attractive option for landlords with property in the central area; it is certainly a better option than renting. One building in central Puebla, with twelve homes and four shops, which was reported to yield 70,000 pesos (less than twice the minimum salary) was on sale for 42 million pesos: another, with a similar number of 'flats' but only two shops, was advertised at 36 million pesos. Even in the central area, however, such sales could not be guaranteed, especially for plots of less than 500 square metres. For smaller properties, prices were much lower: one block of four flats yielding 85,000 pesos per month was advertised for sale at only 7 million pesos.

Selling vacant property, however, still requires eviction of the tenants; this is not an easy task (Gilbert and Varley, 1988). Another method for resolving these dilemmas has therefore emerged: the landlord simply allows the property to fall down around the tenants' ears. This is an extreme solution, but one which was being used in both Central Camionera and Analco. In both areas, vecindades were found in an advanced state of decay. The roof of individual rooms had often fallen in; vacant rooms were filled with rubbish and rubble, and were frequented by rats. The owners did not necessarily trouble to hide what was happening to their properties, since they would even allow the rooms opening onto the street, often used as small shops, to fall into the same state of disrepair. The problem is most severe in Puebla, where the his- 
toric monument legislation which has supposedly protected colonial and nineteenth-century properties since 1977 may actually have had the opposite effect. The legislation severely restricts permissible changes of use, modifications to the fabric of the building etc, thereby hindering the type of conversions in which owners wish to invest. ${ }^{26}$ Many colonial vecindades in Analco and other parts of central Puebla are therefore standing empty, in a state of semi-dereliction. ${ }^{27}$ One study of an area in the centre of Puebla which contained 645 'listed' properties (489 of which were residential) revealed that 45 were wholly or partially abandoned, and 34 of these were already in ruins or in imminent danger of collapse. ${ }^{28}$ In Guadalajara, fewer semi-derelict buildings are to be seen from the streets. Nevertheless, a register in the Municipal Planning Department shows that 109 out of a total of 1,137 vecindades were abandoned, and a further 35 almost deserted. Visiting some of the addresses in Central Camionera which had been registered as vecindades in the $1970 \mathrm{~s}$ revealed some of the changes of use which had taken place since then: one plot was now used as a school; another for warehouses; a third was used partly as offices and partly to repair cars. In the end, most of these properties will either be demolished or be converted to other uses, although one colonial vecindad in Analco was of such architectural interest that a government body was renovating it.

The conclusion to this discussion would appear to be that rental housing in the central areas, and particularly the vecindad, is a form of accommodation which, unless there is a radical change in economic circumstances, is doomed to further decline. Rents are too low to allow adequate maintenance, and many properties would be more attractive if they were cleared and sold as land - or even used as parking lots. In short, the central rental sector appears to be a residual one, with no prospects for success, at least as far as low-income accommodation is concerned. The poor prospects for this sector were well summed up by one man who had been involved in the declaration of central Puebla as a zone of historic and architectural interest: "the historic centres", he said, "cannot survive as low-income housing zones". In his opinion, the best solution would be to "repopulate the area with another type of people". ${ }^{29}$ This chilling vision of the future is one which does not seem, to date, to have evoked any significant political response on the part of the inhabitants of the central areas.

The owners of vecindades in the older self-help settlements would seem to be equally disillusioned with renting and would get out of it if they could. The same does not apply to 'self-help' landlords, all of whom intended to continue renting, at least for the time being. While many complained that it was a bad business and declared that they would not invest money in building rooms to rent in the future, they did not intend to dispose of their property. Some landlords will probably continue to construct to build housing to let. For most of this group, putting money into bricks and mortar is the only type of investment they know anything about. Most of them were once tenants and would share the sentiments of one landlady who declared "I've come up from nothing". Just as they built their own house little by little, they can add 
on extra rooms for rent. What is more logical than to put a little spare cash into extra housing space? Their expectations in renting are more modest than those of a commercial investor; they are therefore less likely to be disappointed by the results. And, even if they do have trouble with some tenants who do not pay the rent, or indulge in rowdy behaviour, what else are they to do with their extra rooms until their children are old enough to need them? They might as well look for a new tenant and hope for better luck next time.

The majority of the 'self-help landlords' sooner or later mentioned their children. A number planned eventually to hand the rented rooms over to them. In other cases, if their children got married and needed somewhere to live for a while, they were prepared to put them up. If they depended very heavily on the rent for their income, they could always charge their children rent. For some, accommodating their offspring was a relief from their dissatisfaction with renting, as in the case of one landlady who had experienced problems with tenants not paying the rent and was gradually installing her children in rooms previously occupied by tenants. In others, it was a response to unexpected circumstances: one landlady in Veinte de Noviembre had added three independent flats to her home, when some of her children had found themselves in financial difficulties. In this case, it was likely to be a temporary situation - "how good it would be if they all went to live independently; we could have more tenants if they did!" It can be seen from this that the replacement of tenants by married children is not a one-way process.

In practice, many landlords were replacing tenants with their own relatives. Eight per cent of tenants in Agustín Yáñez, and 18 per cent of those in Veinte de Noviembre, said they were relatives of the owner. In addition, there was a large number of grown-up children sharing, rent-free. This process could lead either to a situation in which owners, tenants and sharers all lived on the same plot or to one in which the landlord ceased to rent altogether, and the plot was inhabited only by owners and sharers. Together, these two types of plot could actually outnumber the plots occupied by owners and tenants; in Veinte de Noviembre, they accounted for 12 per cent of all residential plots, compared with only 7 per cent of plots with a resident owner and tenants. ${ }^{30}$

It is this flexibility of use that perhaps explains why so many of the 'selfhelp landlords' continue to let accommodation. They are even continuing to build: new landlords were emerging in El Salvador, a self-help settlement on the outskirts of Puebla, although the settlement was only a few years old. At the same time as rental properties in the centre of Puebla were being allowed to fall down around their tenants' ears, houses in El Salvador were being rented out. Even though a large proportion of the settlement area was still uninhabited, five per cent of the residents were already tenants. It is this development of renting hand-in-hand with owner-occupation that provides the only real source of new accommodation for the poor in Mexican cities. 


\section{Conclusion}

For many years rental housing has been in relative decline in Mexico. Since 1982, however, the Mexican government has attempted to encourage more construction for rent. Despite this action, the future for increasing the stock of rental housing as a business proposition looks rather bleak; current state incentives do not seem to have attracted large numbers of investors. Business people do not seem to believe that rental housing has a future. The implications for the Mexican state in this respect seem clear: formal sector renting in the current climate is not an attractive option for the kinds of investors for whom incentives have been created. The irony is that the people who have been responsible for the creation of most new rental accommodation have received no incentives at all. The 'self-help' landlord has received no assistance; yet despite recognising that letting is not really profitable, such people have continued to put labour and capital into additional rooms and buildings.

The possible inference is that the Mexican state should direct more funds towards the small-scale and 'self-help' landlord. Perhaps some kind of credit programme directed towards such investors will yield a high return in terms of new rental accommodation; more monies should perhaps be made available to upgrade deteriorated rental accommodation. However, this is unlikely to happen, if only because the Mexican state is currently so short of funds. It is also unlikely because the Mexican state's attitude towards renting is highly ambivalent. At one level, it recognises the need for more rental accommodation; at another, it refuses to become a social landlord. On the one hand, it provides incentives to professional builders to construct for rent; on the other, it tries to sell deteriorated vecindades to the tenants.

Here, however, is not the place to explore the policy options, especially as we have attempted to do so elsewhere (Gilbert and Varley, 1988). Our intention in this paper has been simpler: merely to provide some kind of portrait of the landlord. This has been necessary because there has been so little work on Mexican landlords. With the exception of scholars such as Coulomb (1985) and Marroquín (1985), most descriptions of landlords in Mexico contain more myth than reality. The picture that emerges from our study is not a totally clear one for it is obvious that landlords in Guadalajara and Puebla are highly diverse, both in their origins and in their form of involvement in renting. What links them is that few find letting a highly profitable activity; indeed, many would like to get out of the business. While there is a group of 'self-help' landlords who are continuing to invest in rental accommodation, many others have become landlords by chance; they are landlords because they have inherited rental property. The paradoxical nature of our findings is clear. Mexico obviously faces a major dilemma in housing its urban population until self-help housing becomes accessible to the majority. At the same time the major alternative tenure option - renting - continues to be unpopular among most landlords. The response of the current government to this paradox will be interesting to observe. 


\section{APPENDIX}

\section{Landlord Case Studies}

The following case studies are chosen to provide illustrations of the nature of landlords in the two cities and the kinds of problems they face. (The data was collected in 1985-86.)

\section{1) Analco, Puebla}

Sra. Delia is a wealthy landlady who lives on more than 5,000 square metres of land, occupied partly by her own house and large garden, and partly by eighteen rented apartments. It is her only property. The whole block was acquired by her mother in the 1940s, but part was sold to a soft-drinks bottling business which still occupies the rest of the block. There were already nine small flats when the property was purchased; Sra. Delia's mother had the rest built around 1950 . The main house is fairly well-maintained, but the rental property is ageing and not in very good condition. Sra. Delia inherited the property from her mother in 1985 . She is a divorced woman in her forties; two of her four children live with her, and are still at school. Sra. Delia works in a travel agency belonging to a friend, earning rather more from her job than she receives each month from the rents. Disregarding anything she may receive from her ex-husband, her income comes to about eight times the minimum salary. At one point in the past, she was herself a tenant, and this makes her rather intolerant with her tenants when they fail to pay the rent on time. When she was a tenant, she said, the first thing she used to do each month was to put aside the money to pay the rent. In general, she has "no patience" with renting, and she is trying to sell off the property to her existing tenants. She has had no success to date.

\section{2) Central Camionera, Guadalajara}

Sr. Gabriel owns a corner plot on which there are four houses. He inherited the property from his father, some eleven years ago, and keeps it mostly for sentimental reasons, "in memory of my parents". He lets two houses, each occupied by a single family, and allows the family of one of his three children to occupy a third. Another married son lives above Sr. Gabriel's own house, 
which he now occupies with his wife. Sr. Gabriel is middle-aged and owns a small business, making machinery for shoe-makers. The business provides the bulk of his income. The rents amount to just over one minimum salary, which he doesn't "take ... into account". Since he is reasonably well-off he is not troubled by the low income he receives from renting: he is not renting, he says, for economic reasons.

\section{3) Central Camionera, Guadalajara}

Sra. Margarita is a widow in her late sixties. She has eight children, none of whom now live with her; instead, a couple of other young relatives share her home. She is comfortably well-off, if not ostentatiously wealthy. She lives in a neat property next door to an equally well-maintained block of four flats which she rents out. She also has eleven flats in a middle-class suburb in the west of Guadalajara; one of these is occupied, rent-free, by a daughter. Her family also own six small commercial and industrial properties, including a small electrical goods and repair shop on one of the city's main shopping streets. The rented houses were built by Sra. Margarita's husband, one at a time, from the late 1950 s onwards. He died seventeen years ago, leaving this property to his widow. The rents from the flats amount to about twice the minimum salary. She lives entirely on these rents and on those from the business properties. Her children help her collect the rents.

\section{4) Analco, Puebla}

Sr. Tomás owns a split-level property on the main street in Analco. At the front are two shops. He lives upstairs around an open patio shared with the three tenant households. Sr. Tomás is clearly not wealthy. He comes from a small town nearby, and travelled widely throughout Mexico before coming to live with his parents in Puebla. He inherited this property when his first wife died, and now lives there with his second wife and their seven children, aged from one to twenty. He is a mechanic, working for the Volkswagen garage in Cholula, and earns the minimum wage. The income from the three flats comes to just over half a minimum salary and he receives more from the two shops downstairs. Although renting is not very remunerative, "any little helps". The rooms are all old, and they are in need of repair; they are unlikely to be done up in the near future.

\section{5) Analco, Puebla}

Sra. Josefina is very poor; indeed, she is herself a tenant, living in two rooms in an old vecindad near Analco. She is a widow, 86 years old, very slight and frail, and hardly able to get about outside the house. She owns a small house with four flats in Analco, which she inherited from her husband when he died in 1980 . They had been married for 55 years but had not had any children; she now lives alone. Sra Josefina has a brother in Mexico City, but does not want to live with him. For a time, she lived with a godson in a village near Puebla, but did not get on well with his family; she therefore moved to her 
present home. She pays a woman friend to look after her at night, in case she is taken ill; this friend sometimes collects the rent for her.

Her husband bought the rented property in 1970, with the intention of providing for himself and his wife in their old age. The couple had been shopkeepers in Los Remedios, near where she now lives; but Sra. Josefina sold the shop. Her rooms in the vecindad are reasonably well-furnished, but she says that she can only pay her own rent if the tenants pay on time. If they get behind with their payments, she sometimes has to borrow money. She finds it very difficult to get them to accept higher rents, although she believes that she could get twice as much money for the flats as she is doing as present. The total income from the rent is the equivalent of three-quarters of a minimum wage.

\section{6) Veinte de Noviembre, Puebla}

Sr. Pablo and Sra. Amelia own one property, where they live with two tenant households and two of their married children. They are an elderly couple, with six other grown-up children. Sr. Pablo is a retired textile factory worker, receiving a pension worth about half the minimum salary. Both he and his wife still work as traders, selling a variety of goods. They have not been doing very well recently, as Sra. Amelia quickly gets tired. As a result, they depend fairly heavily on the rents from the two rented flats, which total about three-quarters of the minimum salary. Occasionally, they have been unable to buy food because their tenants have not paid the rent.

Before moving here, the couple had always lived in vecindades, which they hated; they jumped at the chance to buy this plot, 35 years ago. They built one room plus a kitchen and came to live in Veinte de Noviembre straight away. Over the years, they gradually added the rest of the building, including the two small flats now occupied by the tenants. The second rented flat took five or six years to build, because they were short of money. Eventually, under pressure from people wanting to rent the unfinished rooms, they took out a loan to complete the work.

Renting is not a good business. Sr. Pablo wanted to sell up but Sra. Amelia wouldn't let him: the rent would eke out their income and the property was something to leave to the family. The two children who are living on the plot pay no rent. One is unemployed and the other recently got married and is saving up to buy furniture for his own house; neither can spare anything at the moment.

\section{7) Agustín Yáñez, Guadalajara}

Sr. Antonio is 92 years old, a widower who lives with his 62-year old daughter, her painter husband and one of their daughters (who is a social worker). Another daughter and her family come and go, the husband working in different parts of the country for PEMEX. Sr. Antonio has five other children. He broke his leg about four years ago and is largely confined to the house, 
although he likes to collect the rent himself. It does not come to a great deal of money, but he is pleased with the little he gets.

He used to work in agriculture in a rural area of Jalisco. He came to the city about thirty years ago and rented a room in a vecindad in this same street. About twelve years ago he bought an empty plot, in instalments, and took about a year to build the house. His daughter and her family came to live there later. Five years later, Sr. Antonio started to rent out rooms. He normally has two tenants, keeping one room for his other daughter. He has had some bad luck with tenants not paying the rent. Although he can be badtempered he is not very good at dealing with those who don't pay: "what can you do? They're poor people, just like you." Eventually, he plans to leave his property to his six children.

\section{8) Veinte de Noviembre, Puebla}

Sr. Manuel is a former president of the local residents' association. It is said that he used his post to make a lot of money and he certainly lives in a rather attractive house with a garden. His explanation is that, like several other people in the area, he was able to buy his plot with the help of the electricity workers' union; he was an employee of the generating board. He is about sixty years old and married. One of his two children lives on the same plot with his own family. Sr. Manuel and his wife live on his pension, the interest from a lump-sum he received when he retired, plus the rent. He claims that the rent, about three-quarters of a minimum salary, constitutes a minor part of his income. His four tenants live next door, in a property with a separate street entrance. Sr. Manuel built both buildings with the help of hired labour. Each flat has two bedrooms, a dining room/kitchen and its own services. He started to rent in 1966, and has always had four tenants. Sr. Manuel claims that you couldn't rent similar accommodation elsewhere so cheaply. He does all the repairs himself, but even so renting is not a good business. Nevertheless, it is still better to let the property than to have it standing empty. 


\section{NOTES}

1. Calculated for the twenty largest cities in 1950 and the same cities in $\mathbf{1 9 8 0 .}$

2. This number includes other non-owners in addition to the tenants.

3. 342 owner-occupiers were also interviewed as part of the wider study on which this paper is based. 140 of these owner-occupiers lived in the two consolidated self-help areas to which reference is made in this paper. The rest lived in two peripheral settlements and are not discussed here.

4. Known elsewhere in Latin America by different names such as conventillos, inquilinatos, cortiços, and mesones. While there is no completely satisfactory definition of the term vecindad, most are instantly recognisable in practice. The main door from the street opens onto a communal area, sometimes a patio and sometimes a central passageway. Surrounding this communal area, on one or two storeys, are numerous dark, often windowless rooms. Densities are high, services are communal and usually deficient, and the building is often in poor physical condition.

5. It is to be noted that unlike Monterrey or Chihuahua, Guadalajara and Puebla have few land invasions (Gilbert and Varley, 1988).

6. For our purposes a household was defined as an autonomous group of people living under the same roof who normally eat together and share a common budget to cover the costs of accommodation and subsistence.

7. Tenants were defined as households that pay a prearranged rent for the exclusive occupation of all or part of a house. The accommodation will normally have a separate entrance from those of other households in the same dwelling or plot.

8. It should be noted, however, that the eight flats, which were large units with their own entrance from the street, occupied adjacent plots.

9. It is also possible that the property-owning Lebanese community in the city includes some powerful landlords. The Lebanese community tends to act as a closed group, in this as in other matters; they place their rental property in the hands of the largest rental administrator in Puebla (who refused to provide information for this study).

10. When interviewed, an ex-Governor of the State of Jalisco stated that in the 1950s landlords were normally wealthy, and owned a large number of properties. He quoted two individuals, one of whom, he said, had perhaps twenty vecindades. A representative of the Guadalajara tenants' union suggested that even in more recent years, over half the city's housing stock was in the hands of some 3,000 landlords, giving the improbably high figure of fifty properties per landlord.

11. It should be noted that Tables 1 and 3 cannot be interpreted as referring to the percentage of landlords living in particular places, etc, because more than one tenant could be interviewed in a particular property. This distorts the picture, exaggerating the characteristics of landlords with multi-tenant properties.

12. This accounts for the difference between the mean number of tenant households and the mean number of all households living on the rental properties surveyed in the case-study settlements; a difference which is particularly noteworthy in the case of Puebla (Table 4).

13. See Appendix, Case Study 5. 
14. Twenty-four of the 37 landlords in Puebla reported receiving less than the minimum salary from rent.

15. See for example Appendix, Case Study 5.

16. Inheritance may also account for the large numbers of single-tenant properties, particularly in Guadalajara, and particularly in the older self-help areas. As many as 11 per cent of (all) owners surveyed in Agustín Yáñez, and 25 per cent of those in Veinte de Noviembre, had acquired their property through inheritance or as a gift, usually from their parents. These were resident owners; but the same may well apply to owners who let their inherited homes to a single tenant household. They may keep the property for sentimental reasons, or for later use by their own children. The rent may also serve to supplement their income. Comments made by the tenants of such properties confirm that this is a reasonable interpretation.

17. For many centuries, Puebla grew only slowly and the eastern edge of the barrio was effectively the eastern edge of the city. During the 1940s, La Carbonera, an agricultural property on the edge of the barrio, was subdivided and sold in blocks which now constitute the easternmost blocks of the area designated as Analco, and the 'self-help landlords' are mostly located in this area.

18. This was the rental income of a man with sixteen good-quality flats in Analco.

19. Some landlords in Puebla followed what used to be a legal requirement to register their rental contracts with the State Treasury; several of them said that they had been told they did not need to pay tax because the income they received from renting was too low.

20. See Appendix, Case Study 2.

21. A comment made by a North American ex-patriot who had settled in Guadalajara. He runs a small estate agency, aimed particularly at United States citizens who come to the city to retire. He felt that "there is no economic justification for being in the renting business".

22. He was also lending money to another employee to buy his house, for the same reason.

23. Bank loans for the purchase of existing property were reported to have been suspended at the time of this study.

24. The President of the Asociación Mexicana de Profesionales Inmobiliarios, a Puebla-based association of rental administrators and property developers, claimed that in the past it had been difficult to get people to accept the idea of co-ownership involved in a condominium, but that economic circumstances were now obliging them to do so. Tenants were at first unwilling to buy their rented home, because they did not like to take the risks associated with ownership. Eventually, however, half of those buying their homes are likely to be existing tenants.

25. The frequency of commercial transactions affecting property in Analco is in fact over-estimated by these figures, since only about one-half of the changes of ownership involve entirely commercial transactions (the others involve transfers of property between different members of the same family, by inheritance 'sale', or gift, for example). In all, we may suggest that perhaps one-fifth of the properties in Analco were exchanged on the open market in the last fifteen years; one-third, in the last twenty-five years. 
26. The irresponsibility of certain owners in this respect was indicated by a number of anecdotes told at a meeting of rental administrators and property agents in Puebla; they concluded that there were some owners who would rather see their property destroyed, even against their own economic interests, rather than submit to government regulations concerning preservation of historic monuments.

27. Some detailed case histories are given in Universidad Autónoma de Puebla, DIAU-ICUAP (1984).

28. Presentation by Raúl Contreras, of the Universidad Autónoma de Puebla, to a workshop on 'Las ciudades mexicanas: historia y sociedad', Universidad Veracruzana, Xalapa, April 1986.

29. Presentation by Dr Efraín Castro Morales, former head of the Instituto Nacional de Antropología e Historia in Puebla, to meeting of the Asociación Mexicana de Profesionales Inmobiliarias, August 1986.

30. The difference was smaller in Agustín Yáñez, where plots with owners and tenants accounted for 3 per cent of plots; those with owners and sharers, 4 per cent. 


\section{BIBLIOGRAPHY}

Amis, P. (1982), 'Squatters or tenants: the commercialization of unauthorised housing in Nairobi', paper presented to the Development Studies Annual Conference, Dublin.

Amis, P. (1984),'Squatters or tenants? The commercialization of unauthorised housing in Nairobi', World Development, vol. 12, pp. $87-96$.

Amis, P. (1987), 'Migration, urban poverty, and the housing market: the Nairobi case', in Eades, J. (ed.), Migrants, workers, and the social order (London: Tavistock publications), pp. 249-68.

Armus, D. and Hardoy, J. (1984), 'Vivienda popular y crecimiento urbano en el Rosario del novecientos', Revista Latinoamericana de Estudios Urbano Regionales (EURE), vol. XI, no.31, pp. $29-54$.

Barnes, S.T. (1982), 'Public and private housing in urban West Africa: the rental implications', in Morrison, W.K.C. and Gutkind, P.C.W. (eds.), Housing the urban poor in Africa (New York: Syracuse University), pp. $5-32$.

Beijaard, F. (1986), On conventillos: rental housing in the centre of La Paz, Bolivia, Free University of Amsterdam, Urban Research Working Paper No.5.

Brown, J. (1972), Patterns of intra-urban settlement in Mexico City: an examination of the Turner theory, Cornell University Latin American Studies Program, Dissertation Series 40.

Conway, D. and Brown, J. (1980), 'Intraurban relocation and structure: lowincome migrants in Latin America and the Caribbean', Latin American Research Review, vol.15, pp. $95-125$.

Coulomb, R. (1985), 'La vivienda de alquiler en las áreas de reciente urbanizacíon', A: Revista de Ciencias Sociales y Humanidades, vol.VI, pp. $43-70$.

Cuenya, B. (1986), 'El submercado de alquiler de piezas en Buenos Aires: peculiar expresión de la penuria de vivienda', Los asentamientos populares y el papel de los ONGS en América Latina, vol.3, pp. 3 - 8.

Edwards, M.A. (1982), 'Cities of tenants: renting as a housing alternative among the Colombian urban poor', unpublished $\mathrm{PhD}$ thesis, University of London.

Gilbert, A.G. (1983), 'The tenants of self-help housing: choice and constraint in the housing markets of less developed countries', Development and change, vol.14, pp. $449-77$.

Gilbert, A,G, and Varley, A. (1988), 'Housing tenure and the urban poor in Third World cities', Report submitted to the Overseas Development Association.

Gilbert, A.G. and Ward, P.M. (1982), 'Residential movement among the urban poor: the constraints on housing choice in Latin American cities', Transactions, Institute of British Geographers, no.7, pp. $129-49$.

Gilbert, A.G. and Ward, P.M. (1985), Housing, the state and the poor: policy and practice in three Latin American cities (Cambridge: Cambridge University Press).

Green, G.S. (1988), 'Finding a home in a frontier city: the dynamics of hous- 
ing tenure in Santa Cruz, Bolivia', unpublished $\mathrm{PhD}$ thesis, University of London.

Hoenderdos, W., Van Lindert, P. and Verkoren, O. (1983), 'Residential mobility, occupational changes and self-help housing in Latin American cities: first impressions from a current research programme', Tijdschrift voor Economische et Sociale Geografie, vol.74, pp. 376 - 86.

Malpezzi, S. and Mayo, S.K. (1987a), 'The demand for housing and developing countries: empirical estimates from household data', Economic Development and Cultural Change, vol.35, pp. 687-721.

Malpezzi, S. and Mayo, S.K. (1987b), 'User cost and housing tenure in developing countries', Journal of Development Economics, vol. 25, pp. $197-220$.

Malpezzi, S. and Rydell, C.P. (1986), Rent control in developing countries: a framework for analysis, Water Supply and Urban Development Department, The World Bank, Report No. UDO - 102.

Margulis, M. (1981), 'Crecimiento y migración en una ciudad de la frontera: estudio preliminar de Reynosa', in González Salazar, R. (ed.), La frontera del norte: integración y desarrollo (Jalisco: El Colegio de México).

Marroquín, E. (1985), 'Las vecindades de Puebla', in Gimate-Welsh, A. and Marroquín, E., Lenguaje, ideología y clases sociales. Las vecindades en Puebla (Puebla: Editorial Universidad Autónoma de Puebla), pp. 71 243.

Mayo, S.K. (1985), 'How much will households spend for shelter?', Urban Edge, vol.9, pp. 4 - 5

Méndez Rodríguez, A. (1987), 'Situación de la vivienda en arrendimiento y su impacto en el nivel de vida de los trabajadores', Instituto de Investigaciones Económicas, Universidad Nacional Autónoma de México (mimeo)

O'Connor, A.M. (1983), The African city (London: Hutchinson).

Peil, M. and Sada, P.O. (1984), African urban society (Chichester: John Wiley).

Perló, M. (1981), Estado, vivienda y estructura urbana en el Cardenismo: el caso de la Ciudad de México, Instituto de Investigaciones Sociales, Universidad Nacional Autónoma de México.

Portillo, A.J. (1984), El arrendamiento de vivienda en la Ciudad de México, Cuadernos Universitarios No.5, Universidad Autónoma MetropolitanaIztapalapa.

Ramírez Jiménez, M. (1978), 'Vecindades en Guadalajara', Tesis Profesional, Escuela de Arquitectura, ITESO, Guadalajara.

Scobie, J. (1974), Buenos Aires: Plaza to suburb 1870-1910 (Oxford: Oxford University Press).

Slovik, R. (1972), 'El inquilinato en el DF: un problema socio-económico', Tesis Profesional, Escuela Nacional de Economía, Universidad Nacional Autónoma de México.

Stren, R.E. (1982), 'Underdevelopment, urban squatting, and the state bureaucracy: a case study of Tanzania', Canadian Journal of African Studies, vol.16, pp. $67-91$.

Tipple, A.G. (1988), The history and practice of rent controls in Kumasi, 
Ghana, World Bank, Water Supply and Urban Development Dept., Working Paper No. $88-1$.

Turner, J.F.C. (1967), 'Barriers and channels for housing development in modernizing countries', Journal of the American Institute of Planners, vol.33, pp. $167-81$.

Universidad Autónoma de Puebla, Departamento de Investigaciones Arquitectónicas y Urbanísticas del Instituto de Ciencias (DIAUICUAP) (1984), Crisis del centro histórico y las vecindades, Cuadernos de debate sobre problemas urbanos $4-5$.

Van Lindert, P., (1988), 'La diferenciación del mercado de vivienda en América Latina - el submercado de los conventillos en La Paz, Bolivia', Paper presented to 46th International Congress of Americanists, Amsterdam.

Violich, F. (1944), Cities of Latin America (New York: Reinhardt, Holt and Winston).

Wahab, E.A. (1984), The tenant market of Baldia township: towards a more general understanding of tenancy in squatter settlements, Free University Urban Research Working Paper no.3. 


\section{INSTITUTE OF LATIN AMERICAN STUDIES}

University of London

Publications of the Institute:

Institute of Latin American Studies Monographs

(14 titles in print)

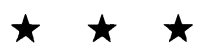

Research and Occasional Papers

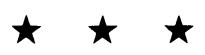

Bibliographies, source lists and other guides

$$
\star \star \star
$$

Handbooks on Latin American Studies and Research on Latin America in the Humanities and Social Sciences in the Universities and Polytechnics of the United Kingdom, giving details of recent publications and theses completed and in progress.

Full details and prices are given in the Publications List available from the Institute.

Institute of Latin American Studies

31 Tavistock Square

London WC1H 9HA

Telephone: 01-387 5671

Fax: 01-388 5024 
Handbooks on Latin American Studies

\section{LATIN AMERICAN STUDIES IN THE UNIVERSITIES AND POLYTECHNICS OF THE UNITED KINGDOM}

Information on undergraduate and postgraduate degree and diploma courses on Latin America and profiles of academic staff

\section{RESEARCH ON LATIN AMERICA IN THE HUMANITIES AND SOCIAL SCIENCES IN THE UNIVERSITIES AND POLYTECHNICS OF THE UNITED KINGDOM}

Publications by academic staff (1984-88) and staff research in progress $\mathrm{PhD} / \mathrm{DPhil}$ and Masters research theses completed (1984-88) and in progress

Price including postage $£ 6.00$ per set ( $£ 8.50$ overseas) or $£ 3.50$ per part ( $£ 5.00$ overseas)

Forthcoming Publication

\section{AN A TO Z OF MODERN LATIN AMERICAN LITERATURE IN ENGLISH TRANSLATION}

\section{From Agosín to Zurita, with an Appendix on Anthologies Jason Wilson}

"Say what you will of its inadequacy, translation remains one of the most important, worthwhile concerns in the totality of world affairs".

(Goethe to Carlyle)

An alphabetical checklist of the fiction, theatre and poetry (and some essays and memoirs) of the Spanish and Portuguese speaking New World since its independence from Europe: 256 authors, 650 published translations and 118 anthologies. This will be a useful bibliographical tool for scholars and librarians and will give the student of comparative literature and the general reader access to the rich and important field of Latin American Literature.

Publication date December 1989. Price to be announced. 


\section{RESEARCH PAPERS \\ (previously Occasional Papers)}

No 1: Oil and Politics in Ecuador, 1972-1976 by George Philip (1978)

No 2: Industrial Investment in an 'Export' Economy: the Brazilian

Experience before 1914 by Flávio Rabelo Versiani (1979)

No 3: Peruvian Labour and the Military Government since 1968 by Alan Angell (1980)

No 4: Labour in Chile under the Junta, 1973-1979 by Gonzalo Falabella 1981)

No 5: W.H. Hudson: the Colonial's Revenge. A Reading of his Fiction and his Relationship with Charles Darwin by Jason Wilson (1981)

No 6: Development Policymaking in Mexico: the Sistema Alimentario Mexicano (SAM) by Michael Redclift (1981)

No 7: Brazilian Private Industrial Enterprise, 1950-1980 by Susan M. Cunningham (1982)

No 8: Bolivia 1980-1981: the Political System in Crisis by James Dunkerley (1982)

No 9: Paraquay in the 1970s: Continuity and Change in the Political Process by James Painter (1983)

No 10: Simón Bolívar and the Age of Revolution by John Lynch (1983)

No 11: The Crisis of the Chilean Socialist Party (PSCh) in 1979 by Carmelo Furci (1984)

No 12: Bonanza Development? The Selva Oil Industry in Peru, 1968-1982 by George Philip (1984)

No 13: The Retreat from Oil Nationalism in Ecuador, 1976-1983 by

Christopher Brogan (1984)

No 14: Harnessing the Interior Vote: the Impact of Economic Change, Unbalanced Development and Authoritarianism on the Local Politics of Northeast Brazil by Scott William Hoefle (1985)

No 15: Caciques, Tribute and Migration in the Southern Andes: Indian Society and the 17th Century Colonial Order (Audiencia de Charcas) by Thierry Saignes (1985)

No 16: The Market of Potosí at the End of the Eighteenth Century by Enrique Tandeter (1987)

No 17: Prostitution in Nineteenth-Century Rio de Janeiro by Luiz Carlos Soares (1988)

No 18: The State and Henequen Production in Yucatán, 1955-1980 by Roberto Escalante (1988) 
